\title{
STRATEGI KOMUNIKASI INTERPERSONAL GURU PADA PENDIDIKAN ANAK USIA DINI SELAMA PEMBELAJARAN JARAK JAUH
}

\author{
I Putu Yoga Purandina a \\ a Sekolah Tinggi Agama Hindu Negeri Mpu Kuturan Singaraja \\ a yogapurandina@stahnmpukuturan.ac.id
}

(Diterima: 07 Juli 2021; Direvisi: 07 Juli 2021; Diterbitkan: 26 Juli 2021)

\begin{tabular}{l}
\hline Keywords: \\
\hline Interpersonal \\
Communication \\
Strategy, Teacher, \\
Remote Teaching
\end{tabular}

Kata kunci:

\begin{tabular}{l}
\hline Strategi \\
Komunikasi \\
Interpersonal, \\
Guru, \\
Pembelajaran \\
Jarak Jauh \\
\hline
\end{tabular}

\begin{tabular}{l} 
Abstract \\
\hline This study aimed to investigate the phenomenon about \\
Teachers' Interpersonal Communication Strategies in remote \\
teaching during Pandemic COVID-19 at Tunas Mekar \\
Kindergarten Tegaljadi Village and to determine the some \\
resistances found in implementing interpersonal \\
communication strategies by teachers during this Pandemic \\
in Tunas Mekar Tegaljadi Village. It used a qualitative \\
descriptive method using observation sheets and interview \\
guides to teachers and parents. As for the results, first, there \\
was three interpersonal communication strategies used by \\
teacher in remote teaching during Pandimic COVID-19 at \\
TK Tunas Mekar; 1) Communication as Action or One-Way \\
Communication, 2) Communication as Interaction or Two- \\
Way Communication, and 3) Multi-Way Communication or \\
Transaction Communication. Second, there was some \\
problem as a resintance found in implementing those \\
communication strategies the most basic was slow response \\
or feedback from students and parents, children quickly get \\
bored or lose focus, and technical problems regarding internet \\
networks.
\end{tabular}

\begin{tabular}{l} 
Abstrak \\
\hline Penelitian ini bertujuan untuk mengetahui fenomena \\
Strategi Komunikasi Interpersonal Guru dalam \\
pembelajaran jarak jauh pada saat Pandemi COVID-19 \\
di Taman Kanak-kanak Tunas Mekar Desa Tegaljadi \\
dan untuk mengetahui hambatan yang ditemukan \\
dalam penerapan strategi komunikasi interpersonal \\
\hline
\end{tabular}


oleh guru selama Pandemi di Desa Tunas Mekar Tegaljadi. Metode yang digunakan adalah metode deskriptif kualitatif dengan menggunakan lembar observasi dan pedoman wawancara kepada guru dan orang tua. Adapun hasilnya, pertama, ada tiga strategi komunikasi interpersonal yang digunakan guru dalam remote teaching saat Pandimic COVID-19 di TK Tunas Mekar; 1) Komunikasi sebagai Tindakan atau Komunikasi Satu Arah, 2) Komunikasi sebagai Interaksi atau Komunikasi Dua Arah, dan 3) Komunikasi Banyak-Arah atau Komunikasi Transaksi. Kedua, terdapat beberapa kendala yang ditemukan dalam penerapan strategi komunikasi tersebut yang paling mendasar adalah respon atau feedback yang lambat dari siswa dan orang tua, anak cepat bosan atau kehilangan fokus, dan masalah teknis terkait jaringan internet.

\section{PENDAHULUAN}

Hampir satu tahun sudah lamanya bangsa ini dirundung kemalangan akibat Pandemi COVID19. Dari pertengahan Maret 2020 diumumkannya secara resmi oleh pemerintah mengenai kasus pertama COVID-19 ini. Hal ini mengakibatkan segala sektor mengalami pelemahan. Baik sektor kesehatan yang merupakan terkena dampat yang berat. Kemudian sektor ekonomi, sektor industri sektor pariwisata, serta sektor pendidikan (Bramasta, 2020). Hampir semua pihak dilemahkan dan menelan kerugian. Banyak masyarakat yang terkena pemutusan hubungan kerja. Terutama dari sektor pariwisata dan industri. Kemudian tentu akan berimbas ke sektor ekonomi di mana akan terjadi daya beli masyarakat yang lesu dan melemahkan usaha kecil menengah di tengah-tengah masyarakat (Soleha, 2020).
Lebih parah lagi pemerintah baik pemerintah pusat maupun pemerintah daerah telah beberapa kali melakukan kebijakan penanggulangan penyebaran Pandemi COVID-19 ini (Wiguna \& Ekaningtyas, 2021). Dari tindakan yang bersifat tegas sampai pada tindakan yang refresif (Gitiyarko, 2020). Tindakan tegas misalnya jika ada yang melanggar protokol kesehatan tentu akan diberikan sanksi teguran, sesuatu yang bersifat mendidik, hingga pada tindakan penjara. Kebiajakan pemerintah ini tentu dengan maksud untuk mengatur berbagai teknis di lapangan, demi sebuah keteraturan untuk menjaga masyarakat supaya tidak terkena wabah ini.

Diketahui bahwa Pandemi COVID-19 ini diakibatkan oleh virus COVID-19 merupakan istilah lain dari SARS-CoV-2 (Severe Acute Respiratory Syndrome Corona Virus 2). Virus yang sangat berbahaya menyerang sistem 
pernafasan manusia (Saxena, 2020). Sehingga pemerintah akhirnya menginformasikan kebijakan mengenai protokol kesehetan. Semua masyrakat, begitu pula institusi negeri maupun swasta harus mematuhi protokol kesehatan ini. Hal yang paling sederhana yang dikenal masyarakat adalah dengan menerapkan 3M, yaitu memakai masker, mencuci tangan, serta menjaga jarak (Hakim, 2020).

Dengan demikian di segala sektor melalui kementerian terkait mengeluarkan berbagai kebijakan yang mengatur segala teknis kehidupan masyrakat. Baik di sektor kesehatan, transportasi publik, sektor kerja, serta serktor pendidikan. Berulang kali berbagai sektor ini mengalami perubahan aturan kebijakan selama Pandemi COVID-19 ini. Hal ini disesuaikan dengan keadaan dan kondisi di lapangan, bahkan saat ini diberikan kepada daerah untuk kebijakan lebih lanjut tergantung warna zona pada daerah tersebut (Kementerian Luar Negeri Republik Indonesia, 2020).

Terutama di Provinsi Bali saat ini sebagian besar wilayahnya masih dalam keadaan zona merah dan oranye. Hal ini menunjukkan bahwa Bali dalam keadaan darurat COVID-19. Dengan demikian seluruh stake holder berupaya untuk mengatur masyrakat untuk lebih waspada terhadap virus ini. Sampai saat ini di Bali, segala tindakan dan sosialisai masyarakat masih tetap dipantau (Dinas Kesehatan
Provinsi Bali, 2020). Jika kasus COVID19 meningkat maka akan dberlakukan jam malam dan berbagai pengaturan jam kerja, bahkan pada suatu kondisi diterapkan BDR (Bekerja Dari Rumah) (Aprian, 2020).

Di sektor pendidikan, khususnya di Bali selalu dipantau kondisi di daerah masing-masing kabupaten dan kota. Memang merujuk SKB menteri tentang penyelenggaraan pendidikan pada masa Pandemi COVID-19 ini diserahkan kepada dinas pendidikan di daerah untuk memutuskan apakah sekolah dapat dibuka untuk pemebelajaran tatap muka atau tidak. Bahkan orang tua serta kepala sekolah memutuskan anak atau siswa boleh ke sekolah untuk pembelajaran tatap muka secara langusng atau tidak, walaupun misalnya dinas pendidikan di daerah sudah membuka sekolah untuk tatap muka (Kementerian Pendidikan dan Kebudayaan, 2020).

Keadaan yang tidak berangsurangsur membaik ini membuat anak didik semakin lama mengalami pembelajaran dari rumah atau Pembelajaran Jarak Jauh (PJJ). Selama hampir setahun pula anak didik belajar dari rumah. PJJ ini mengandalkan pembelajaran daring (dalam jaringan) dengan memanfaatkan teknologi digital (internet) untuk sebuah pembelajaran dengan menstrasfer berbagai informasi yang disampaikan kepada anak didik yang berada di rumah dengan sebuah platform 
pembelajaran seperti Whatsapp, Google Classroom, Webex, Zoom Meeting, dll. (Syaharudin, 2020).

Hal ini lah membuat dunia pendidikan kita menjadi berubah 180 derajat, karena satu satunya solusi yang bisa ditawarkan dalam dunia pendidikan terutama dalam proses belajar mengajar yaitu dengan melakukan pembelajaran daring (remote teaching/ online learning/ online classroom). Kondisi ini seperti memberikan shock of therapy bagi guru dan sosen, siswa dan mahasiswa (Purandina, 2020a). Banyak guru terutama guru, belum mengenal apa itu pembelajaran daring dan bagaimana melakukannya. Demikian pula dengan pula siswa masih belum familiar dengan pembelajaran daring. Memang selama ini dunia pendidikan kita seakan-akan acuh terhadap pembelajaran online dan sangat lambat perkembangannya di Indonesia khususnya di Bali (Purandina \& Winaya, 2020b)

Pembelajaran daring ini tentu sangat bergantung ke pada jaringan internet, perangkat atau alat telekomunikasi (gawai), serta biaya yang diakibatkan oleh kebutuhan kuota paket internet masing-masing anak. Hal ini tentu sangat membebankan baik guru sendiri, orang tua serta anak didik sendiri (Putria et al., 2020). Walaupun dibeberapa daerah di Bali atau di suatu sekolah kadang menerapkan pendekatan PJJ kombinasi. Yaitu tidak selalu mengandalkan pembelajaran daring, namun dikombinasikan dengan pembelajaran luring (luar jaringan). Pembelajaran dengan sistem luring ini didesain dengan memberikan intruksiintruksi (penugasan) pembelajaran ke pada anak didik tanpa menggunakan teknologi internet (Malyana, 2020). Guru memberikan tugas yang bisa diambil langsung ke sekolah oleh orang tua, kemudian dikumpulkan kembali melalui orang tua ke pada guru (Wiguna, 2021).

Memang PJJ merupakan sebuah pilihan yang sulit untuk dilakukan, namun inilah yang terbaik yang dapat dilakukan saat ini. PJJ tentu memiliki kelebihan dan kelemahan tersendiri. Kelebihannya, dengan PJJ pembelajaran menjadi lebih mudah diakses, lebih fleksibel terhadap waktu dan tempat, mudah mencari sumber belajar yaitu di dunia maya, biaya mungkin bisa tergolong lebih murah (relatif) (Purandina \& Winaya, 2020a). Akan tetapi di sisi lain PJJ banyak menimbulkan berbagai permasalahan (Basar et al., 2021). Permasalahan yang paling mendasar adalah kedtiidak siapan sektor pendidikan terutama guru, pihak sekolah, bahkan pemerintah sendiri masih belum begitu menguasai PJJ ini terutama dalam pembelajaran daring. Begitu pula masyarakat terutama orang tua dan anak didik lumayan dibuat kebingungan dengan sistem PJJ ini (Wahyono et al., 2020). 
Di dalam pembelajaran daring, guru belum terbiasa menggunakan berbagai platform pembelajaran, belum biasa mendesain pembelajaran daring yang efektif, serta menentukan kegiatan, media, serta sumber pembelajaran daring. Hal ini sebenarnya disebabkan oleh kurangnya kemampuan guru dalam penguasan teknologi informasi terutama teknologi digital (Rigianti, 2020).

Selain juga disebabkan oleh kurangnya infrastruktur teknologi digital di tengah-tengah masyarakat, khususnya di daerah atau daerah terpencil, masalah timbul akibat kurang komunikasi yang baik anta guru dengan anak didik serta kurangnya komunikasi guru ke pada orang tua. Sebelumnya pada pembelajaran tatap muka guru dengan mudahnya dapat berinteraksi dengan anak didik di sekolah secara langsung. Guru akan dengan menyampaikan pembelajaranya yang berupa informasi atau pengetahuan. Guru juga dengan mudah meberikan motivasi, penjealasan tambahan sehingga mempermudah anak didik dalam menerima pelajarannya.

Interaksi guru dengan anak didik sangatlah penting. Di sini akan terjalin sebuah ikatan yang tidak sekedar ikatan guru dan anak didik melainkan ikatan orang tua dengan anaknya (Purandina, 2020c). Hal inilah pada saat Pandemi COVID-19 ini terasa hilang. Interaksi ini sanagatlah sulit dilakukan pada PJJ. Banyak guru belakangan merasa gagal menjadi guru, bahkan guru yang telah puluhan tahun mengajarpun merasa gagal dalam pembelajarannya. Anak didik di rumah merasa frustasi, bosan, dan kurang memahami setiap pembelajaran yang diberikan oleh guru mereka (Putro, 2020). Orang tua juga terkena imbas dimana pada PJJ ini malah memiliki peran yang cukup penting. Orang tua di rumah menjadi memiliki tugas ekstra yang harus mendampingi anaknya menerima pembelajaran. Orang tua juga harus mampu mejadi jembatan anatar guru dengan anak didik (Purandina, 2020b).

Masalah-masalah yang muncul ini tentu tidak boleh sampai malah menambah permasalahan Pandemi COVID-19. Guru harus kreatif mencari jalan yang terbaik sehingga pembelajarannya dapat berjalan secara efektif. Selain harus kreatif dalam mengetahui kondisi anak didiknya, guru juga harus mampu menentukan merode, strategi media, sumber belajar bagi anak didiknya. Di samping itu, guru juga harus memiliki strategi komunikasi yang baik dan tepat dalam berkomunikasi dengan anak didik serta orang tua. Komunikasi yang baik tentu akan menimbulkan persepsi yang baik pula. Komunikasi di sini termasuk komunikasi dalam memberikan pembelajaran, motivasi, serta komunikasi yang menenangkan anak didik dan orang tua pada masa Pandemi COVID-19 ini. 
Seperti yang terjadi di TK Tunas Mekar, Desa Tegaljadi, Kecamatan Marga, Kabupaten Tabanan. TK Tunas Mekar, Desa Tegaljadi ini sangat percaya akan pentingnya strategi komunikasi selama PJJ ini belangsung. Sejatinya anak didik di Taman Kanakkanak (TK) atau Pendidikan Anak Usia Dini (PAUD) belum mampu menjalani PJJ. Di masa kanak-kanak ini mereka semestinya belajar bersosialisasi dengan guru, teman serta orang lain, belajar berbagai soft skill, pengembangan diri dengan melakukan aktivitas atau kegiatan di sekolah.

Maka para guru berfikir dan mencari solusi yang terbaik (Ratna, 2020) untuk mendesain PJJ yang efektif untuk anak usia dini. Tetapi dengan mencoba berbagai metode guru-guru di TK Tunas Mekar memilih platform Whatsapp sebagai kelas virtual, dimana dengan grup Whatsapp guru bisa berkumpul bersama anak didik yang diwakilkan oleh akun Whatsapp orang tua mereka. Sehingga orang tu secara langsung dapat mengontrol pembelajaran anak mereka. Aplikasi Whatsaap dipilih karena aplikasi ini sudah familiar di kalangan orang tua. Selain itu aplikasi ini dipilih karena mudah melakukan komunikasi baik secara messanger atau berkirim pesan, broadcasting, sharing informasi, serta video live conference. Sejatinya Whatsapp merupakan aplikasi komunikasi, namun di sini dimanfaatkan sebagai kelas virtual yang fleksibel sehingga memudahkan komunikasi dengan anak didik dan orang tua (Cetinkaya, 2017).

Para guru di TK Tunas Mekar, Desa Tegaljadi berupaya untuk membuat pembelajaran yang menyenangkan. Sebelumnya anak didik sering mengalami kejenuhan ketika mengalami Pembelajaran Jarak Jauh (PJJ), sehingga membutuhkan kreativitas guru dalam membangkitkan semangat belajar mereka. Berkaitan dengan permasalahan tersebut, maka salah satu cara yang dilakukan guru di TK Tunas Mekar, Desa Tegaljadi adalah melalui strategi komunikasi interpersonal.

Komunikasi interpersonal adalah proses pengiriman dan penerimaan pesan-pesan antara dua orang atau di antara kelompok kecil orang-orang dengan umpan balik seketika (Hapsurani et al., 2018). Mengacu pada penelitian yang dilakukan oleh Warsita (2014), strategi komunikasi interpersonal dapat dapat dilakukan secara tatap muka maupun menggunakan media komunikasi elektronik seperti email, sosial media, telepon, video interaktif yang dikontrol dengan komputer (video conference), serta tutorial online menggunakan jaringan internet.

Lebih lanjut, komunikasi interpersonal merupakan bentuk khusus dari komunikasi antar manusia yang terjadi bila kita bereaksi secara simultan dengan orang lain dan saling mempengaruhi secara mutual satu 
sama lain, interaksi yang simultan memiliki arti bahwa para pelaku komunikasi memiliki tindakan yang sama terhadap suatu informasi pada waktu yang sama pula (Pontoh, 2013).

Terdapat tiga strategi komunikasi ntuk mengembangkan interaksi dinamis yang dapat digunakan antara guru dengan siswa, antara lain: 1) Komunikasi Sebagai Aksi atau Komunikasi Satu Arah, 2) Komunikasi Sebagai Interaksi atau Komunikasi Dua Arah, dan 3) Komunikasi Banyak Arah atau Komunikasi Transaksi (Asgarwijaya, 2015). Pembelajaran Di dalam proses pembelajaran, siswa memerlukan sesuatu yang memungkinkan mereka berkomunikasi secara baik dengan guru, teman, lingkungannya maupun dengan. Oleh karena itu, komunikasi yang baik antara guru, anak didik akan menentukan keberhasilan belajar anak didik terutama pada saat PJJ ini.

Seperti pada penelitian yang dilakukan oleh Komariah \& Purwati tahun 2019 di Kabupaten Bima, ditemukan beberapa cara yang menentukan keberahasilan dalam sebuah komunikasi interpersonal dalam pemebelajaran PAUD yaitu dengan melakukan percakapan, tanya jawab dengan anak, melakukan dialog, dan sharing (Komariah \& Purwati, 2019). Kemudian penelitian oleh Nurhayati tahun 2020 di Banjarmasin dimana komunikasi interpersonal diterapkan untuk membuat anak lebih mandiri dan berkarakter (Nurhayati,
2020). Begitu pula penelitian sebelumnya dilakukan oleh Ahmad pada tahun 2020 menemukan bahwa komunikasi interpersonal dapat membentuk anak lebih aktif, cerdas dan berkarakter (Ahmad, 2020). Dengan demikian komunikasi interpersonal haruslah dilakukan oleh guru PAUD untuk pembelajaran yang lebih baik.

Dalam hal ini setiap anak didik dan orang tua tentu memiliki asumsi yang berbeda-beda dalam setiap pembelajaran. Mereka tentu juga memiliki cara yang berbeda dalam cara belajar dan mencari sumber belajarnya. Sehingga jika hal ini tetap dibiarkan maka PJJ ini akan gagal. Maka dari itu guru percaya dengan memberikan startegi komunikasi interpersonal kepada anak didik dapat membuat anak didik dan orang tua memiliki pemahaman yang sama terhadap suatu pembelajaran. Anak dan orang tua akan diberikan penjelasan secara interpersonal, sehingga pembelajaran menjadi lebih bermakna dan dapat difahami secara holistik.

Berdasarkan peparan fenomena di atas pada akhirnya peneliti tertarik untuk melakukan investigasi lebih lanjut mengenai Strategi Komunikasi Interpersonal Guru pada Pembelajaran Jarak Jauh di TK Tunas Mekar, Desa Tegaljadi, Tabanan. Dengan penelitian ini nantinya diharapkan terjalin interaksi yang baik antara guru dan anak didik walaupun pembelajaran diselenggarakan secara jarak jauh. Serta 
menjadi bahan rujukan penelitian berikut mengenai strategi komunikasi guru pada PJJ.

\section{METODE}

Penelitian ini merupakan penelitian deskriptif kualitatif. Data diperoleh dengan menggunakan pendekatan kualitatif yang lebih menekankan pada kualitas data yang diperoleh mengenai Strategi Komunikasi Interpersonal Guru pada Pembelajaran Jarak Jauh di TK Tunas Mekar I \& II, Desa Tegaljadi, Kecamatan Marga, Tabanan. Kualitas data di sini sesuai dengan situasi sosial yang terdiri dari tiga unsur yaitu tempat, pelaku, dan kegiatan, dan peneliti secara langsung mengamati secara mendalam fenomena atau situasi sosial yang terjadi di lapangan. Sehingga peneliti memiliki peran sentral dalam penelitian ini (Creswell \& Creswell, 2017).

Subjek penelitian ini adalah guru TK Tunas Mekar I dan II yang terdiri dari 5 (lima) guru. Guru TK Tunas Mekar ini telah memiliki pengalaman lebih dari lima tahun dan bahkan ada yang sampai puluhan tahun. Rata-rata umur subjek penelitian berkisar dari umur 25 tahun samapai dengan 50 tahun. Subjek penelitian di sini bergabung pada kelas virtual Whatsaap yang melakukan komunikasi dan interaksi dengan anak didik dan orang tua.

Dalam penelitian ini, peneliti menganalisis strategi komunikasi guru dangan anak didik menggunakan aplikasi Whatsapp pada saat Pandemi COVID-19 di TK Tunas Mekar I \& II, Desa Tegaljadi, Tabanan. Dengan menggunakan 2 (dua) instrumen selain peneliti sendiri sebagai Instrumen Kunci (Key Instrument). Adapun 2 (dua) instrument tersebut berupa instrumen lembar observasi untuk melakukan observasi langsung di kelas. Kelas yang digunakan saat ini adalah kelas onlie atau kelas daring yaitu melalui WhatsApp. Penulis ikut serta bergabung ke dalam kelas daring dalam group Whatsaap.

Selain itu, pedoman wawancara juga digunakan untuk memperoleh data tentang persepsi orang tua terhadap penggunaan Strategi Komunikasi Interpersonal Guru pada Pembelajaran Jarak Jauh. Tujuan dibuatnya instrumen ini tentunya untuk mendapatkan data yang dapat menjawab permasalahan penelitian yaitu bagaimanakah Strategi Komunikasi Interpersonal Guru pada Pembelajaran Jarak Jauh di TK Tunas Mekar, Desa Tegaljadi pada saat Pandemi COVID-19 ini. Mengetahui hambatan dan solusi yang dapat ditanggulangi dalam Komunikasi Interpersonal Guru pada Pembelajaran Jarak Jauh di TK Tunas Mekar, Desa Tegaljadi, Tabanan.

Secara umum peneliti merupakan instrumen utama dalam penelitian ini. Peneliti menganalisis data yang diperoleh melalui observasi langsung dan pembelajaran di kelas 
pada anak TK Tunas Mekar, Desa Tegaljadi, Tabanan. Grup tersebut berupa kelas daring yang menggunakan aplikasi WhatsApp (Purandina, 2021). Peneliti langsung bergabung dengan grup WhatsApp bersama guru, siswa yang didampingi oleh orang tuanya. Kemudian, pedoman wawancara juga digunakan untuk mewawancarai guru dan orang tua. Bagian wawancara dilakukan melalui obrolan dan panggilan di WhatsApp kepada guru dan orang tua. Instrumen tersebut telah divalidasi oleh para ahli di bidang pendidikan terutama para pakar peneliti di bidang strategi komunikasi pendidikan atau interasi kelas dan merupakan instrumen yang tepat untuk memperoleh data dalam penelitian kualitatif ini, khususnya dalam melakukan metode penelitian deskriptif kualitatif. Instrumen ini berperan penting dalam memperoleh data melalui proses mengamati dan memperoleh data.

Untuk mendapatkan data yang baik dan tepat diperlukan data yang valid dan reliabel. Sehingga data yang diperoleh harus dicek ulang dan diulang sehingga didapat data yang valid yang disebut dengan data Triangulasi (Connelly, 2016). Triangulasi data merupakan suatu pendekatan atau cara untuk memperoleh data yang akurat dengan menggunakan berbagai teknik pengumpulan data. Dalam penelitian ini dilakukan dengan menggunakan berbagai teknik pengumpulan data seperti pedoman observasi dan wawancara. Sehingga tentunya data yang diperoleh akan dicocokkan dan dibandingkan untuk mendapatkan data yang valid (Roulston, 2018).

Dalam menganalisis data, peneliti menggunakan tiga konsep atau teknik analisis data yang dikenalkan oleh Miles-Hubermans. Adapun konsep tiga pendekatan ini yaitu, pertama reduksi data yang langsung dilakukan pada pengumpulan data, kedua penyajian data (display data), dan yang ketiga adalah verifikasi data / Drawing cloncussion (Sugiono, 2019). Pendekatan analitik ini merupakan kegiatan yang dilakukan secara langsung yang berisi tentang proses penyelidikan masalah atau fenomena yang terjadi. Setelah data diperoleh, maka akan langsung dianalisis sebagai bentuk proses investigasi. Analisis data di sini dilakukan secara interaktif dan simultan hingga semua masalah dalam penelitian ini terjawab atau diperoleh solusi. Reduksi data dilakukan dengan sangat hati-hati dimana hanya data yang diperlukan yang diambil sesuai dengan permasalahan penelitian. Data yang dimaksud tentunya sesuai dengan Strategi Komunikasi Interpersonal Guru pada Pembelajaran Jarak Jauh di TK Tunas Mekar, Desa Tegaljadi, Kecamatan Marga, Kabupaten Tabanan. Data yang didapatkan akan dilakukan proses reduksi yaitu dengan mengabaikan atau membuang data yang tidak 
diperlukan atau mendapatkan data yang berulang ulang sehingga menjadi jenuh.

\section{PEMBAHASAN}

Setelah selama tiga bulan peneliti melakukan observasi terhadap komunikasi dan interaksi guru pada kelas virtual yaitu grup Whatsapp, serta melakukan wawancara terhadap guru dan orang tua anak didik sehingga memperoleh data yang jenuh. Data juga telah mengalami reduksi data dengan membuang data yang tidak dibutuhkan dan membandingkan dengan data yang sama atau jenuh. Analisis data dilakukan sepenuhnya dengan menggunakan teori komunikasi interpersonal yang dibagi menjadi tiga 1) Komunikasi Sebagai Aksi atau Komunikasi Satu Arah, 2) Komunikasi Sebagai Interaksi atau Komunikasi Dua Arah, dan 3) Komunikasi Banyak Arah atau Komunikasi Transaksi (Asgarwijaya, 2015).

Dengan demikian didapatkan data strategi komunikasi interpersonal guru pada pembelajaran jarak jauh di TK Tunas Mekar, Desa Tegaljadi yang terbagi menjadi tiga kategori. Yang pertama adalah 1) Komunikasi Sebagai Aksi atau Komunikasi Satu Arah, 2) Komunikasi Sebagai Interaksi atau Komunikasi Dua Arah, dan 3) Komunikasi Banyak Arah atau Komunikasi Transaksi.
A. Strategi
Komunikasi Interpersonal Guru di TK Tunas Mekar

\section{Komunikasi sebagai Aksi atau Komunikasi satu arah.}

Dalam stretegi komunikasi interpersonal yang termasuk kategori ini lebih banyak guru yang aktif dalam berkomunikasi memberikan informasi. Dapat dikatakan sebagai metode ceramah, dimana biasanya guru meberikan suatu informasi umum, misalnya dalam meberikan intruksi atau petunjuk dalam mengerjakan sebuah aktivitas. Contohnya pada saat guru TK Tunas Mekar II, menenagkan anak didik ketika menanggapi pemebelajaran daring melalui Video Call Whatsapp.

\section{Excerpt 1}

"Anak-anak dan Ibu semuanya, tolong tenang jangan ribut pehatikan ibu guru mau menjelaskan tentang air, api, dan udara ya!"

\section{Excerpt 2}

"Anak-anak ibu matikan mikrophonenya ngih, supaya tidak ada suara yang bising masuk sehingga menggangu aktivitas video call kita hari ini. Barusan ibu dengar suara kendaraan lewat."

Pada kutipan 1 (Excerpt 1) percakapan guru pada kelas daring melalui Whatsapp Video Cenference enunjukkan strategi komunikasi interpersonal satu arah di mana guru meminta anak didik untuk fokus mendengarkan penejlasan ibu guru tanpa adanya tanggapan dari anak didik lebih lanjut. Sedangkan pada kutipan 2 (Excerpt 2) guru mematikan (mute) microphone anak didik supaya suara bising keadaan di lingkunagan anak didik tidak menggangu proses 
pembelajaran. Kedua kutipan ini menujukan sebuah komunikasi yang tidak menginikan adanya balikan atau feedback berupa komunikasi balasan, namun lebih kepada tindakan yang fasif.

\section{Komunikasi sebagai Aksi atau Komunikasi Dua Arah.}

Dalam stretegi komunikasi interpersonal yang termasuk kategori komunikasi dua arah ini pemeberi aksi dan penerima aksi memiliki peranan yang sama. Komunikasi terjadi dengan melakukan komunikasi secara personal atau dengan mengarahkan atau menujukkan komunikasi kepada seseorang atau individu. Komunikasi ini membatasi kepada satu individu, tidak melibatkan individu lainnya. Individu lainnya tidak dapat mengikuti komunikasi ini.

\section{Excerpt 3}

"Tugek Putri bagaimana warna matahari, apakaha berwarna kuning? Merah? Atau putih?" "Kuning Bu guru."

\section{Excerpt 4}

"Semangat ya De Agus mengerjakan tugasnya" "Terimakasih sudah mengupulkan tugasnya." "Ingat tetap jaga kesehatan ya!"

\section{Excerpt 5}

"Bu Fitri nanti nunas tulung ngih Fitrinya dibimbing untu mewarnai dengan rapi ngih!. "Jangan lupa foto pada sembahyang dikirim ngih, suksma." "Inggih Bu Guru Kadek, Suksma."
Pada kutipan 3 (Excerpt 3) guru berdiskusi dengan salah satu anak didik dengan menanyakan warna dari mathari yang berarti ibu guru meminta tanggapan atau balikan dari anak didik. Kemudian anak didik di sini menanggapi dengan menjawab warna matahari adalah berwarna kuning. Sedangkan pada kutipan 4 (Excerpt 4) Ibu guru memberikan motivasi dan berterimakasih ke pada salah satu anak didik dengan melakukan chatting langsung secara individu dengan anak didik tersebut. Kemudian pada kutipan 5 (Excerpt 5) Bu Guru melakukan chatting pribadi dengan salah satu orang tua siswa untuk mengingatkan dan menghimbau orang tua tersebut untuk membimbing anaknya untuk mewarnai dengan rapi dan tidak lupa untuk mengirimkan foto pada saat anak melakukan persembahyangan.

Pada kutipan 3, 4, dan 5 ini sangat terlihat bahwa guru melakukan strategi komunikasi dua arah dimana guru melakukan komunikasi seara personal terhadap satu individu baik di sini anak didik maupun orang tua. Komuniksi di sini terjadi secara dua arah di mana aksi yang diberikan oleh guru diterima dan diberikan balikan aksi oleh penerima aksi sebelumnya. Strategi komunikasi ini dapat meningkatkan interaksi personal yang baik anatara guru dengan anak didik serta orang tua. Strategi komunikasi ini juga akan menumbuhkan rasa percaya diri bagi setiap individu penerima aksi karena terdapat aksi berupa rasa peduli 
dari guru terhadap perkembangan anak didik di dalam pembelajaran teruutama pembelajaran jarak jauh (PJJ).

\section{Komunikasi Banyak Arah atau} Komunikasi Transaksi.

Strategi komunikasi jenis ini memungkinkan seseorang untuk melakukan komunikasi ke banyak pihak secara dinamis. Secara dinamis di sini adalah komunikasi anatar guru dengan anak didik, guru dengan orang tua, anak didik dengan anak didik lainnya, serta orang tua dengan orang tua lainnya. Proses belajar mengajar dengan cara komunikasi ini mengarah kepada proses pengajaran yang. Mengembangkan kegiatan siswa yang optimal sehingga menumbuhkan siswa belajar aktif, sebagai contoh adalah diskusi dan simulasi yang merupakan strategi yang dapat mengembangkan komunikasi dua arah.

Pada komunikasi jenis ini aakan terjadi pertukaran informasi yang kompleks pada suatu keajdian atau pada suatu masa. Seperti halnya diskusi dengan sebuah kelompok tertentu. Mendapatkan balikan atau feedback dari banyak arah. Hal ini biasanya terjadi pada grup Whatsapp yang terdiri dari anak didik atau orang tua siswa dalam kelas virtual pembelajaran jarak jauh. Komunikasi jenis ini mendominasi atau sebagian besar digunakan dalam sebuah komunikasi pada grup Whatsapp (kelas virtual).

\section{Excerpt 6}

"Selamat pagi, bpk ibuk, anakanakku, selamat tahun baru, semoga ditahun baru 2021 ini, covid cepat menghilang, dan anak mendapat beajar kembali seperti biasanya, dan anak anak sll berdoa terus bersama keluarga di rumah."

Excerpt 7

"Selamat pagi bunda bunda. Mohon list kan no yg bisa diisikan pulsa di sini ya...

1. (Nama anak.../ Nomor.. ya)

2.

\section{Excerpt 8}

"Selamat pagi bpk/ibuk ini link nya untuk satu minggu ke depan ini link terakhir ya, semester satu yg minggu 17, makasi selamat mengerjakan anak anak." "ini nyanyian sakit gigi." "Apakah materi sebelumnya ada yang belum dipahami?"

\section{Excerpt 9 \\ 9}

"Kepada yth

Para orang tua murid TK Tunas Mekar I

di tempat

Dengan hormat

Berhubung kegiatan pembelajaran semester 1 berakhir......."

Pada kutipan 6 (Excerpt 6) guru mengucapkan selamat tahun baru 2021 pada grup Whatsapp. Pesan tersebut ditujukan kepada para anak didik serta para orang tua. Kemudian ditanggapi oleh anak didik serta orang tua dengan selamat dan harapan serta doa. Sedangkan pada kutipan 7 (Excerpt 7) Ibu guru menginformasikan mengenai pendataan nomor handphone anak didik atau orang tua yang dipakai untuk akses pembelajaran jarak jauh 
untuk nantinya mendapatkan bantuan berupa kuota internet. Pada kutipan 8 (Excerpt 8) bu guru memberikan atau membagikan materi berikutnya untuk minggu ke 17 di semester satu. Ibu guru memberikan link yang terhubung dengan berbagai materi yang disimpan pada google drive. Di sini bu guru juga menanyakan permasalahan atau kendala pada materi sebelumnya. Pada kutipan 9 (Excerpt 9) Ibu guru dalam hal ini Kepala TK Tunas Mekar II mengundang orang tua sisswa untuk menghadiri rapat virtual yang diadakan pada akhir semester.

Pada kutipan 6, 7, 8, dan 9 ini menunjukkan sebuah strategi komunikasi banyak arah atau transaksional. Ibu guru melakukan komunikasi dengan mengirimkan informasi pada grup Whatsapp yang tergabung di dalamnya anak didik serta orang tua. Terdapat pula pesan yang bersifat broadcasting atau informasi umum kepada semua orang yang berada pada grup Whatsaap tersebut. Di samping itu guru juga menggunakan strategi ini untuk mengetahui permasalahan anak didik dengan menanyakan permasalahan anak didik yang terjadi selama proses pembelajaran. Terjadi juga komunikasi saling menanggapi antar orang tua dengan saling memberikan motivasi dan memperjelas informasi yang diberikan oleh ibu guru sebelumnya, jika ada beberapa informasi yang belum dipahami oleh orang tua. Begitu pula anak didik terbiasa saling tegur sapa pada grup Whatsapp atau pun pada Video Call sebagai balikan dari komunikasi guru yang transaksional sebelumnya.

\section{B. Hambatan dalam Strategi Komunikasi Interpersonal Guru di TK Tunas Mekar}

Dalam pengimplementasian komunikasi interpersonal yang baik dan efektif kepada anak didik dan orang tua, guru tentu menemukan berbagai permasalahan di sini yaitu paling mendasar adalah kurangnya balikan atau feedback dari anak atau orang tua. Hal ini terjadi karena biasanya di pagi hari orang tua membawa gawai mereka untuk bekerja sehingga pemebelajaran yang diberikan oleh guru di pagi hari sedikit mendapat tanggapan. Tanggapan atau feedback dari orang tua sering kali terlambat sampai paling lama hingga satu minggu. Hal ini telah disiasati oleh guru dengan memberikan aktivitas selama satu minggu untuk menanggapi aktivitas atau tugas yang diberikan.

Kemudian hambatan lainnya adalah hambatan seperti sifat alamian anak yang cepat bosan dan kurang fokus. Hal ini terlihat ketika diadakan pembelajaran melalui video conference di mana anak-anak terlihat cepat kehilangan fokus dalam pemebelajaran (Irwansyah et al., 2021). Hal ini juga telah disiasati dengan cara melakukan strategi komunikasi dua arah dnegan berkomunikasi langsung dan memotivasi anak didik. Masalah lainnya adalah berupa masalah teknis 
seperti jaringan internet yang sering terganggu atau kualitas internet yang labil membuat proses komunikasi menjadi terganggu.

\section{SIMPULAN}

Pada masa Pandemi COVID-19 ini dunia pendidikan menjadi lebih sulit untuk diselenggarakan. Sehingga pembelajaran jarak jauh (PJJ) tidak terhelakkan untuk dilaksanakan. Anak didik pada jenjang Taman Kanakkanak ini memnag harus mendapatkan interkasi yang lebih baik dan lebih interaktif oleh guru. Oleh karena itu guru di TK Tunas Mekar, Desa Tegaljadi, Kecamatan Marga, Kabupaten Tabanan melakukankan variasi straetgi komunikasi interpersonal kepada anak didik dan orang tua. Terdapat tiga kategori strategi komunikasi interpersonal guru kepada anak didik dan orang tua pada pembelajaran jarak jauh di TK Tunas Mekar. Yang pertama adalah Komunikasi Sebagai Aksi atau Komunikasi Satu Arah. Kedua, Komunikasi Sebagai Interaksi atau Komunikasi Dua Arah. Ketiga, Komunikasi Banyak Arah atau Komunikasi Transaksi. Di samping itu ditemukan pula berbagai permasalaahan yang menghambat terciptanya komunikasi interpersonal yang efektif seperti lambatnya tanggapan atau feedback dari anak didik dan orang tua, anak cepat bosan atau kehilangan fokus, dan masalah teknis mengenai jaringan internet.

\section{DAFTAR PUSTAKA}

Ahmad. (2020). Analisis Deskriptif

Komunikasi Interpersonal Dalam Proses Belajar Mengajar Di Sekolah. Jurnal Sultra Anak Bangsa Kajian Ilmu Pendidikan Anak Usia Dini, 53(9), 1689-1699.

Aprian, D. (2020). Bali Terapkan Jam Malam Menjelang Pergantian Tahun Selama 4 Hari.

Kompas.Com.

Asgarwijaya, D. (2015). STRATEGI KOMUNIKASIINTERPERSONA LANTARA GURU DAN MURID PAUD (Studi Deskriptif Komunikasi Interpersonal Antara Guru dan Murid PAUD Tunas Bahari Dalam Kegiatan Belajar Mengajar). E-Proceeding of Management, 2(1), 1008.

Basar, A. M., Islam, P. A., Nurul, S., Cikarang, F., \& Bekasi, B. (2021). Problematika Pembelajaran Jarak Jauh Pada Masa Pandemi Covid-19( Studi Kasus di SMPIT Nurul Fajri Cikarang Barat-Bekasi) A . Pendahuluan kemampuan, sikap , dan bentuk-bentuk tingkah laku yang bernilai positif. Hal itu untuk pencipta . Pendidikan s. 2(1), 208218.

Bramasta, D. B. (2020). Mengenal Apa Itu New Normal di Tengah Pandemi Corona... Artikel ini telah tayang di Kompas.com dengan judul "Mengenal Apa Itu New Normal di Tengah Pandemi Corona..." Kompas.Com.

Cetinkaya, L. (2017). International Review of Research in Open and Distributed Learning The Impact of Whatsapp Use on Success in Education Process. International Review of Research in Open and 
Distributed Learning, 18(7), 1-8.

Connelly, L. M. (2016).

Trustworthiness in qualitative research. MedSurg Nursing, 25(6), $435+$.

Creswell, J. W., \& Creswell, J. D. C. (2017). Reseach Design; Qualitative, Quantitative, Mix Methodes Approaches (1st ed.). SAGE Publications Inc.

Dinas Kesehatan Provinsi Bali. (2020). Bali Waspada Virus Corona.

Diskes.Baliprov.Go.Id.

Gitiyarko, V. (2020). Upaya dan Kebijakan Pemerintah Indonesia Menangani Pandemi Covid-19. Kompas.Com.

Hakim, L. (2020). Disiplin 3M, Kunci Utama Tekan Penularan Covid-19. Kementerian Komunikasi Dan Informastika Republik Indonesia. Hapsurani, F. Y., Fitriawan, R. A., \& Aprianti, A. (2018). PENERAPAN BINA BICARA DALAM KOMUNIKASI INTERPERSONAL GURU DAN SISWA TUNARUNGU SLB-B SUKAPURA KIARACONDONG. 5(1), 1349-1358.

Ida Bagus Alit Arta Wiguna. (2021). Kepemimpinan Kepala Sekolah PAUD Di Masa Pandemi Covid-19. 221-233.

https://doi.org/https://doi.org/ 10.33363/sn.v0i1.63

Ida Bagus Alit Arta Wiguna, K. A. T. R. D. (2020). Strategi Guru Dalam Peningkatan Mutu Pembelajaran Etika Hindu. Jurnal Penjaminan Mutu, 6(2), 210-220.

https://doi.org/DOI:

http://dx.doi.org/10.25078/jpm. v6i2.1449

Irwansyah, R., Darmayani, S.,

Mastikawati, M., Saputro, A. N.
C., Wihartanti, L. V., Fauzi, A., Arifudin, O., Purandina, I. P. Y., Latifah, E. D., Septiyani, T., Pangestika, R. R., Fatayah, F., Ayuningtyas, P., Lemba, V. C., \& Hartono, R. (2021).

PERKEMBANGAN PESERTA DIDIK . In Widina Bhakti Persada Bandung. Widina Bhakti Persada Bandung.

Kementerian Luar Negeri Republik Indonesia. (2020). KEBIJAKAN PEMERINTAH REPUBLIK INDONESIA TERKAIT WABAH COVID-19. Kemlu.Go.Id.

Kementerian Pendidikan dan Kebudayaan. (2020). Pemerintah Daerah Diberikan Kewenangan Penuh Tentukan Izin Pembelajaran Tatap Muka.

Komariah, S., \& Purwati, N. (2019). KOMUNIKASI INTERPERSONAL GURU DALAM PEMBENTUKAN KARAKTER ANAK DI TK AL_AZZAM DESA KANANGA KECAMATAN BOLO KABUPATEN BIMA. Komunikasi Dan Kebudayaan, 6(April), 57-67.

Malyana, A. (2020). Pelaksanaan Pembelajaran Daring dan Luring Dengan Metode Bimbingan Berkelanjutan Pada Guru Sekolah Dasar Di Teluk Betung Utara Bandar Lampung. Jurnal Ilmiah Pendidikan Dasar Indonesia, 2(1), 67-76.

Nurhayati. (2020). KOMUNIKASI INTERPERSONAL DALAM KEGIATAN BELAJAR MENGAJAR. Mutakkalimin Jurnal Ilmu Komunikasi, 3(1), 23-27. https:// doi.org/https:/ / doi.org/ 10.1234/jab.v1i1.20

Pontoh, W. P. (2013). PERANAN 
KOMUNIKASI

INTERPERSONAL GURU

DALAM MENINGKATKAN

PENGETAHUAN ANAK. Acta

Diurna, I(I), 1-11.

Purandina, I. P. Y. (2020a). 'PLUS-

MINUS’PEMBELAJARAN

DARING BAHASA INGGRIS

SELAMA PANDEMI COVID-19.

In M. Yusuf (Ed.), Pengalaman

Pembelajaran Bahasa Inggris Daring

di Perguruan Tinggi pada Masa

Pandemi Covid-19 (p. 153).

Deepublish.

Purandina, I. P. Y. (2020b). Pendidikan

Karakter Tumbuh Subur di

Lingkungan Keluarga selama

Pandemi COVID-19. In COVID-

19: Perspektif Pendidikan (pp. 99-

114). Yayasan Kita Menulis.

Purandina, I. P. Y. (2020c). THE USE

OF ENGLISH CLASSROOM

GREETING AND CHARACTER

BUILDING IN TK PELITA SARI

DESA MAMBANG TABANAN.

Jurnal Pendidikan Bahasa Inggris

Indonesia, 8(2), 12-19.

https://doi.org/10.23887/jpbi.v8i 2.3495

Purandina, I. P. Y. (2021). Whatsapp Sebagai Solusi Keterbatasan Guru Dengan Anak Didik Pada Saat Pandemi Covid-19 Di TK Tunas

Mekar Desa Tegaljadi. Widyacarya Jurnal Pendidikan, Agama $\mathcal{E}$ Budaya, 5(1), 1-11.

Purandina, I. P. Y., \& Winaya, I. M. A. (2020a). Berkarakter dalam Literasi Digital : Menjaga Kedamaian Umat di Era Digital. 1-18.

Purandina, I. P. Y., \& Winaya, I. M. A. (2020b). Pendidikan Karakter di Lingkungan Keluarga Selama Pembelajaran Jarak Jauh pada Masa Pandemi COVID-19. Cetta:
Jurnal Ilmu Pendidikan, 3(2), 270290.

https:// doi.org/10.37329/cetta.v 3i2.454

Putria, H., Maula, L. H., \& Uswatun, D. A. (2020). Analisis Proses pembelajaran Dalam Jaringan (DARING) Masa Pandemi COVID-19 pada Guru Sekolah Dasar. Jurnal Basicedu, 4(4), 861872.

https://doi.org/10.31004/basiced u.v4i4.460

Putro, K. dkk. (2020). Pola interaksi anak dan orangtua selama kebijakan pembelajaran di rumah. Fitrah: Jurnal of Islamic Education, 1(1), 124-140.

Rigianti, H. A. (2020). KENDALA PEMBELAJARAN DARING GURU SEKOLAH DASAR DI KABUPATEN

BANJARNEGARA. Elementary School, 28(2), 1-43.

Roulston, K. (2018). Triangulation in qualitative research. QualPage.

Saxena, S. K. (2020). Coronavirus Diseas 2019 (COVID-19): Epidemoogy, Pathogenis, Diagnosis, and Therapeutics.

Soleha, A. R. (2020). Kondisi UMKM Masa Pandemi Covid-19 Pada Pertumbuhan Ekonomi Krisis Serta Program Pemulihan Ekonomi Nasional. Jurnal Ekombis, 6(2), 165-178.

Sugiono. (2019). Metode Penelitian Kualitatif. Afabeta.

Syaharudin, S. (2020). Pembelajaran Masa Pandemi: dari Konvenstional ke Daring. EPrint.Ulm.Ac.Id.

Wahyono, P., Husamah, H., \& Budi, A. S. (2020). Guru profesional di masa pandemi COVID-19: 
Review implementasi, tantangan, dan solusi pembelajaran daring. Jurnal Pendidikan Profesi Guru, 1(1), 51-65.

Wiguna, I. B. A. A., \& Ekaningtyas, N. L. D. (2021). STRATEGI ORANG
TUA DALAM MENDAMPINGI ANAK USIA DINI BELAJAR DARING DI RUMAH. Pratama Widya: Jurnal Pendidikan Anak Usia Dini, 6(1), 86-95. 